\section{Lorenzo Gotte (1926-1991): a pioneer of elastin}

Lorenzo Gotte (1926-1991) was an outstanding histologist at the School of Medicine of Padua. This year marks the $25^{\text {th }}$ anniversary of his passing away - commemorated during the recent congress of the Italian Society for the Connective Tissue (SISC), held in Padua (September 30 - October 1, 2016). This brief note recalls this outstanding figure: indeed, for those who knew him, Lorenzo Gotte was an exceptional scientist and at the same time, an unparalleled teacher - and, for many, a great friend. It is still difficult to separate these aspects of his personality, so intertwined in his life: studying elastin and elastic tissue was a passion central to Gotte's life.

Born on $15^{\text {th }}$ August 1926 in Noventa Padovana, a small town just outside Padua, he completed his education in Padua and read medicine at the local university where he graduated in 1950. In the same year he was appointed lecturer in histology and general embryology and till 1960 alternated his scientific activity between the Institute of Histology and that of Biological Chemistry in Padua. Meanwhile, as a doctor, he became a specialist in cardiology, while in 1957 he gained a lectureship ('libera docenza') in histology. In 1965 he was appointed full professor of histology and general embryology in the faculty of medicine, and from 1970 was also responsible for lectures on human anatomy in the faculty of pharmacy. From 1970 till 1984 he directed the Institute of Histology while in 1989, after the death of Alessandro Castellani, he was elected president of SISC.

His early scientific career began in the decade from 1950, with investigation of particular aspects of the cardiovascular system such as the ultrastructure of the myocardium, the histochemistry of the impulse-conducting system of the heart, and the ultrastructure and biomechanical properties of the artery extracellular matrix. ${ }^{1-3}$ In these studies he used a combination of morphological and biochemical approaches, shifting progressively towards a methodological approach akin to that of a structural biochemist. It was through his work in the fifties that his original observations, preliminary investigations and inspired speculations led him to define the guidelines and pinpoint the subjects of his later scientific activity. These were chiefly the structural duality of elastic fibres; the structural features of bovine (ligamentum nuchae) and human arterial elastin studied through electron microscopy; the biomechanical properties of elastic fibres from vessels and nuchal ligament; and the biochemical and ultrastructural features of calcification and ageing in the elas- tic fibres from human arteries. ${ }^{4-7}$

In 1960-61 in Cambridge as a Rockfeller Fellow, at the Low Temperature Research Station directed at that time by Prof. Partridge, he worked on the biochemistry of elastic fibres from different bovine tissues, approached new methods of biochemical investigation (particularly quantitative amino acid analysis) and completed some studies started in Padua. ${ }^{8,9}$ After this spell in England, he returned to Padua.

Among his many scientific achievements, Gotte's clear definition of elastic fibres, as composed of an elastin core associated with glycoproteins (and proteoglycans) may be considered a landmark in the study of elastic tissues. His findings were later supported by numerous experimental studies and taken up by other investigators, and still today underpin leading investigations on the structure and physiology of elastic tissues. ${ }^{10-13}$ After defining the elastic fibre as a more complex system, Gotte's research group in Padua identified the elastin-associated glycoprotein as the site of age-related deposition of calcium salts in human arteries, and through successive studies on the binding of calcium ions, provided an almost conclusive definition of the role of elastin itself in the process of calcification. ${ }^{14-15}$

However, the most acclaimed results obtained by Gotte are probably those related to the fibrillar model of elastin at odds with the isotropic models drawn from conventional electron microscopy and high angle x-ray diffraction studies. ${ }^{16}$ This fibrillar model, arising from his early work, and confirmed over the years through increasingly refined experimentation, remains the subject of a passionate debate in the scientific community. It also sparked off a number of investigations carried out in an attempt to reconcile apparently conflicting experimental results. Many other aspects of elastin's physical chemistry were also investigated and clarified through Gotte's studies - these include the role played by water and the influence of other solvents on the biomechanical properties of the elastic fibre.

Moreover, through far-UV circular dichroism analysis, Gotte obtained the first experimental evidence of order in the structure of elastin and postulated the presence of the alpha-helix conformation in soluble degradation products (alpha-elastin) as well as in insoluble native elastin. ${ }^{17}$ These findings set off a new field of investigation into the structure of elastin, based on the use of soluble elastin degradation products and of synthetic polypeptides reproducing the most frequent repeating sequences in elastin. In addition, Gotte is also well known for his work over the years on the role of elastin in the architecture of the extracellular matrix of arteries, and the modality of its

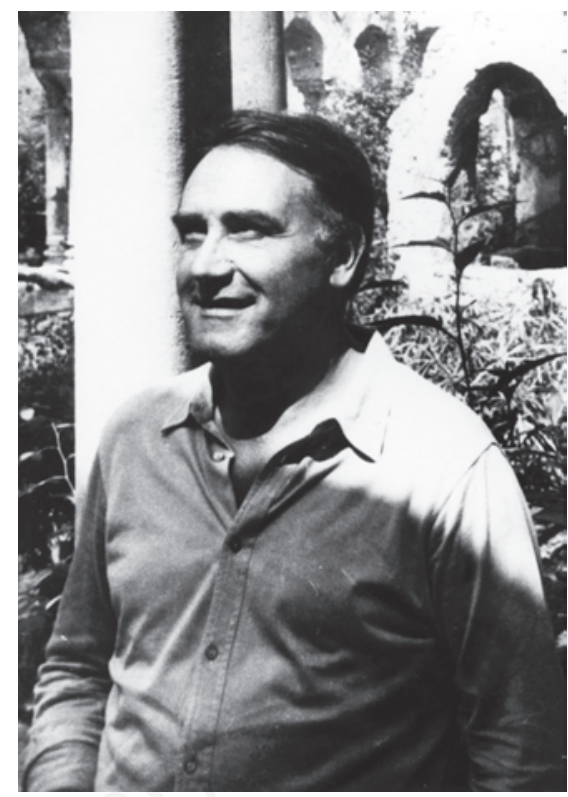

degradation by elastolytic enzymes (focus of many other groups). Here too he proposed original procedures, an animal and an in vitro model, designed to follow the progression of elastin degradation in vivo. ${ }^{18,19}$

It is quite clear that Gotte's significant contribution to the study of elastin and elastic tissue were very much enhanced by his multidisciplinary approach to biological problems. Instead of describing and analysing as is the tradition of morphological sciences, his major thrust was to understand how structure was linked to morphology and function (possibly at molecular level). To this end he adopted investigatory procedures ranging from classic histology and electron microscopy to the most sophisticated and technologically advanced methodologies of chemistry, physics and physical chemistry. Here he often sought the collaboration of scientists with perhaps minimal knowledge of biological investigation, but whose interest was aroused by Gotte's enthusiasm and ingenuity in suggesting application of exact sciences to resolving his biological problems. His passion was contagious, and he promoted a wide range of studies on elastin, particularly in Italy. Through the impetus of Gotte and colleagues a number of major research groups on elastic tissue were established in Padua, Bologna, Modena and Potenza.

Just as Partridge might be considered the founder of modern research investigation on elastin, Gotte could be seen as a pioneer in view of his methodological approach to the study of elastin structure and the completely fresh hypotheses he made early on. Of particular note is his introduction for the first time in Padua of the quantitative amino acid analysis, on his return from Cambridge. Under his inspiring activity, the Institute of Histology once housing microscopes, a glorious but old- 
fashioned tissue culture section and an ancient balance - became a modern, wellequipped research centre at top international level. He succeeded in overcoming local difficulties through the strength of his persuasion as well as his enthusiasm and passion, which also shone through in his manner and ability to communicate with people. Even so, he was unconventional in his scientific conceptions, and ironically was unable to compromise sometimes to his disadvantage - while his directness could at times be an obstacle in dayto-day life and work.

Gotte should also be remembered as an inspiring teacher: his passion alongside his clear and always up-to-date style meant he was well known not only among students and colleagues, but also outside the academic milieu. Interestingly, despite being a dyed-in-the-wool 'structural biochemist', he was also proud to have been responsible for courses on anatomy for over thirty years.

He died in Padua on $27^{\text {th }}$ December 1991 and his funeral, following his precise wish, was celebrated outside the officialdom of the university. The Church of the Immacolata in Via Belzoni was crowded with many deeply saddened people, including friends and colleagues from throughout Italy, students, authorities and ordinary people, all united in mourning the loss of a great scientist and a person able to communicate his deep humanity.

Along with so many others, we share the great honour of having known Lorenzo Gotte.

M. Onisto, S. Garbisa, M. Spina
Department of Biomedical Sciences
University of Padua, Italy

\section{References}

1. Gotte L, Munari PF. [Preliminary report on the submicroscopic structure of the heart muscle and the bundle of His in Bos taurus].[Article in Italian]. Boll Soc Ital Biol Sper 1953;29:338-9.

2. Pittoni A, Gotte L. [Relation of myocardial metabolism to its conduction tissue. I. Respiratory quotient, anaerobic glycolysis, and cocarboxylase content].[Article in Italian]. Arch Sci Biol (Bologna) 1953;37:525-32.

3. Gotte L, Munari PF. [Preliminary report on the elasticity of the aorta and pulmonary artery].[Article in Italian]. Boll Soc Ital Biol Sper 1953;29:339-42.

4. Gotte L, Munari PF. [Electron microscopy observations on the elastic fibers].[Article in Italian]. Boll Soc Ital Biol Sper 1954;30:814-6.

5. Gotte L, Moret V. [Possible relation between mucopolysaccharides (hexosamine) and protein part in elastin].[Article in Italian]. Boll Soc Ital Biol Sper 1958;34:822-3.

6. Bucciante G, Gotte L. [Morpho-chemical studies of senile elastin].[Article in Italian]. Arch Sci Biol (Bologna) 1958;42:490-4.

7. Gotte L, Rizzi R. [Histochemical findings on the aorta \& pulmonary artery in hypertensive patients].[Article in Italian]. Minerva Cardioangiol Eur 1957;5:383-8.

8. Gotte L, Stern P, Elsden DF, Partridge SM. The chemistry of connective tissues. 8 . The composition of elastin from three bovine tissues. Biochem J 1963;87:344-51.

9. Gotte L, Serafini-Fracassini A. Electron microscope observations on the structure of elastin. J Atheroscler Res 1963;3:247-51.
10. Gotte L, Serafini-Fracassini A, Moret V. The chemical composition of the NaCl-soluble fraction from autoclaved elastin. $\mathrm{J}$ Atheroscler Res 1963;3:244-7.

11. Moret V, Serafini-Fracassini A, Gotte L. The carbohydrate composition of the $\mathrm{NaCl}$ soluble fraction from autoclaved elastin. J Atheroscler Res 1964;4:184-8.

12. Gotte L, Giro MG, Volpin D, RW Horne. The ultrastructural organization of elastin. J Ultrastruct Res 1974;46:23-33.

13. Volpin D, Pasquali-Ronchetti I, Urry DW, Gotte L. Banded fibers in high temperature coacervates of elastin peptides. J Biol Chem 1976;251:6871-3.

14. Palumbo M, Terbojevich M, Cosani A, Peggion E, Gotte L. Interaction of calcium ions with alpha-elastin. Peptides: structure and biological function. Proceedings 6th American Peptide Symposium; 1979; pp. 715-8.

15. Molinari Tosatti MP, Gotte L, Moret V. Some features of the binding of calcium ions to elastin. Calcif Tissue Res 1971;6:329-34.

16. Mammi M, Gotte L, Pezzin G. Evidence for order in the structure of alpha-elastin. Nature 1968;220:371-3.

17. Mammi M, Gotte L, Pezzin G. Comparison of soluble and native elastin conformations by far-ultraviolet circular dichroism. Nature 1970;225:80-1.

18. Papajiannis SP, Spina M, Gotte L. Sequential degradation and phagocytosis of heterologous elastin. Arch Pathol 1970;89:434-9.

19. Caenazzo C, Spina M, Onisto M, Fastelli G, Gotte L, Agostini C, et al. Degradation of immobilized soluble elastin by tumor cells in culture: quantitation by ELISA. Int $\mathrm{J}$ Cancer 1990;46:552-8. 